\title{
Modulation of Antibiotic Efficacy against Klebsiella pneumoniae by Antihistaminic Drugs
}

Tarek El-Said El-Banna, Fatma Ibrahim Sonbol, Ahmed Ahmed Abd El-Aziz and Omnia Momtaz Al-Fakharany*

Pharmaceutical Microbiology Department, Faculty of Pharmacy, Tanta University, Egypt

\begin{abstract}
Antihistaminic drugs are widely used for various indications during microbial infection. Hence, this paper has investigated the antibacterial activity of seven antihistaminic drugs belonging to both old and new generations against multiresistant $K$. pneumonia isolates. The bacteriostatic activity of these tested drugs was investigated by determining their MIC by agar dilution technique against thirty multiresistant $K$. pneumoniae isolates. Two drugs namely promethazine, cyproheptadine showed antibacterial activity against the tested $K$. pneumoniae isolates with MIC values rangining from $400-1000 \mu \mathrm{g} / \mathrm{ml}$ (far more than their biological levels). In contrast, other tested drugs showed no in-vitro antibacterial activity under the conditions of test. Investigation of the interaction between the tested drugs and different antibiotics against multiresistant $K$. pneumoniae isolates revealed that synergism was major in case of combination with macrolides, aminoglycosides and quinolones especially with promethazine, cyproheptadine, cetirizine and diphenhydramine. The effect of tested drugs on antibiotic efflux by the tested isolates was also investigated. It was observed that promethazine and cyproheptadine were the most effective efflux pump inhibitor at a concentration of $100 \mu \mathrm{g} / \mathrm{ml}$. Upon studying the effect of tested drugs on biofilm formation by $K$. pneumoniae, it was found that promethazine was the most effective inhibitor of biofilm formation. It reduced biofilm formation by $K$. pneumoniae in a concentration-dependent manner and prevented biofilm formation at a concentration of $100 \mu \mathrm{g} / \mathrm{ml}$. In the present study, it was found that the use of $100 \mu \mathrm{g} / \mathrm{ml}$ chlorpheniramine resulted in the conversion of separate rod shape of $K$. pneumoniae cells into long filaments. This was confirmed by transmission electron microscope where septum formation with no separation was recorded. In conclusion, the data obtained in this work showed that, among the tested drugs promethazine and cyproheptadine exerted high antibacterial activity against MDR K. pneumoniae isolates. So, it is possible to take the advantages of the obtained findings to introduce new ways to overcome different infectious diseases.
\end{abstract}

Keywords: Non-antibiotics; Antihistaminics; Antibacterial activity; Antibiotic-drug combinations; Biofilm; Efflux pump inhibitor

\section{Introduction}

Although antibiotics are the most imperative weapons in combating bacterial infections, over the past few decades the use of antibiotics is becoming increasingly restricted. The noted dramatic increase in the incidence of severe, life-threatening infections in addition to the recent spread of new multi-resistant variants in the hospital and community created a need for more effective antimicrobial therapy. Combinations of antibiotics are commonly used in medicine to broaden antimicrobial spectrum and generate synergistic effects. Alternatively, combination of non-antibiotic drugs with antibiotics offers an opportunity to sample a previously untapped expanse of bioactive chemical space. A collection of drugs were screened to identify compounds that augment the activity of antibiotics. Unexpected synergistic drug combinations exhibited in vitro and in vivo activity against bacterial pathogens, including multidrug resistant isolates [1]. Devising compounds that interfere with efflux of active antibiotics from the cell is an attractive strategy for the design of modified or combination therapeutics $[2,3]$. There is evidence in the literature that certain non-antibiotic compounds, alone or in combination with conventional antibiotics, may play a useful role in the management of specific bacterial infections associated with a high risk of resistance to conventional antibiotics $[4,5]$. Examples of these non-antibiotic drugs, antihistaminics, mucolytics, local anaesthetics, antihypertensive drugs, anti-depressants and anticoagulants. These drugs are often administrated with antibiotics; concomitant use may enhance, diminish, modify or even eliminate the expected antimicrobial activity of different categories of antibiotics as a result of their interaction at the physical, chemical and / or biological level. Some studies have reported that non-antibiotics interfere with the growth of certain bacteria and also lead to reversal of resistance in multiple drug resistant pathogens. Other studies found that these drugs may decrease antibacterial activity of different antibiotics.

A histamine antagonist (commonly called an antihistamine) is a pharmaceutical drug that inhibits the action of histamine. It is commonly used for the relief of allergies caused by intolerance of proteins [6]. Drugs with antihistamine action are the most commonly prescribed medication in daily dermatologic practice, both to adults and children [7]. Histamine is a potent mediator of numerous physiologic reactions. It exerts its effects on target cells in various tissues by binding to its four receptors: histamine receptor HR1, HR2, HR3, and HR4 [8]. In common use, the term antihistamine refers only to compounds that inhibit action at the $\mathrm{H} 1$ receptor (and not $\mathrm{H} 2$, etc.).

Antihistaminics comprise a broad class of pharmacological agents. Depending on their effects on the central nervous system (CNS), antihistaminics are divided into "classic" or first generation antihistaminics, relatively sedating H1antagonists, and the newer, less or nonsedating $\mathrm{H} 1$ antagonists, second generation class. Several of these new compounds also exhibit anti-cholinergic and anti-

*Corresponding author: Al-Fakharany OM, Pharmaceutical Microbiology Department, Faculty of Pharmacy, Tanta University, Egypt, Tel: 2040 3344352; E-mail: momtaz_omnia@yahoo.com

Received December 14, 2015; Accepted March 21, 2016; Published March 26, 2016

Citation: El-Banna TES, Sonbol FI, El-Aziz AAA, Al-Fakharany OM (2016) Modulation of Antibiotic Efficacy against Klebsiella pneumoniae by Antihistaminic Drugs. J Med Microb Diagn 5: 225. doi:10.4172/2161-0703.1000225

Copyright: (c) 2016 El-Banna TES, et al. This is an open-access article distributed under the terms of the Creative Commons Attribution License, which permits unrestricted use, distribution, and reproduction in any medium, provided the original author and source are credited. 
inflammatory properties that are independent of their action on the $\mathrm{H} 1$ receptor. Other developments, generally in the form of active metabolites or enantiomers, led to the use of the term "third generation" antihistaminics [9]. They can be also classified on the basis of chemical structure, and agents within these groups have similar properties. The typical antihistaminics have an ethylamine side chain (similar to that of histamine itself) which is united to one or more cyclic groups. The structural characteristics of the $\mathrm{H} 1$ receptor antagonists have been historically used for classifying them into six broad chemical family's ethanolamines, ethylenediamines, alkylamines, phenothiazines, piperazines and piperidines [10].

Gram-negative bacterial strains [11,12]. Moreover, some phenothiazine antihistaminics showed certain anti-tuberculosis activity $[13,14]$ demonstrated that certain phenothiazine antihistaminics could be adsorbed onto the surface of the bacterial cells which might facilitate their effect on bacterial cell membranes. Azelastine and cyproheptadine exhibited remarkable killing activities mainly against the gram-positive isolates. Inhibition of plasma membrane based efflux pumps have been observed with a variety of phenothiazines and their derivatives [15]. Azelastine, a new generation phthalazinone derivative, demonstrated significant bacteriostatic activity which was more pronounced against the tested Gram-positive. It showed moderate activity against the tested E. coli and Klebsiella spp. strains [16]. Methdilazine, diphenhydramine, bromodiphenhydramine and promazine reduced the mortality rate in mice challenged Salmonella typhimurium, provided that the drug was administered before challenge [17-19].

As previous studies were almost restricted to studying the effect of antihistaminic drugs on the bacterial susceptibility to different antibiotics, while the possible mechanisms of interactions of these drugs with different antibiotics at the molecular level almost received no attention from the microbiological point of view. For that reason, this paper has dealed with the microbiological testing of possible activities of seven antihistaminics belonging to both old and new generations using antibiotic multiresistant K. pneumonia clinical isolates. Also, in this paper we have investigated the possible mechanisms of interactions of these drugs with different antibiotics against the tested $K$. pneumoniae isolates at the phenotypic and molecular levels.

\section{Materials and Methods}

\section{Microorganisms}

A total of 50 clinical isolates of $K$. pneumoniae were used in this study. They were obtained from the culture collection of microbiology department, faculty of pharmacy, Tanta University, Egypt. In addition, reference K. pneumoniae strain (ATCC 13883) was used. Purity and identity of the tested isolates and standard strain were confirmed according to [20] while maintenance of pure culture of each strain was done by subculturing in vials containing soft nutrient agar and storage at $4^{\circ} \mathrm{C}$ for short term maintenance (about 6 months). Long term maintenance was achieved by suspending the isolate in $20 \%$ dimethylsulphoxide (DMSO) in sterile nutrient broth and storage at $-20^{\circ} \mathrm{C}$ for (about 1 year).

\section{Antimicrobial agents}

Powders of antimicrobial agents, used in this study, were obtained as reference samples from pharmaceutical companies. The following antimicrobial agents were used: Amikacin, AK, (BMS, USA); Amoxacillin, AMX, (Sigma, USA); Ampicillin, AMP, (Sigma, USA); Azithromycin, AZI, (Pfizer, USA); Cefotaxime, CTX, (Aventis, Germany); Cefaclor, CEF, (Ranbxy, England); Cephalexine, CN, (GSK,
England); Chloram-phenicol, CM, (Sigma, USA); Ciprofloxacin, CIP, (Ranbxy, England); Erythromycin, ERY, (Abott, USA); Gentamicin, GN, (Schering Plough, USA); Levofloxacin, LEV, (Aventis, Germany); Moxifloxacin, MOX, (Schering, Germany); Ofloxacin, OFX, (Aventis, Germany); Oxytetracycline, OXT, (Nasr, Egypt); Streptomycin, STR, (Sigma, USA). They were preserved at $4^{\circ} \mathrm{C}$.

\section{Culture media}

\section{Oxoid pre-made culture media}

MacConkey's agar, Muller-Hinton agar, Nutrient agar, Nutrient broth, Tryptic soy broth. The dehydrated pre-made culture media were prepared as described by the manufacturers, sterilized by autoclaving at $121^{\circ} \mathrm{C}$ for $15 \mathrm{~min}$, distributed into petri dishes (solid media) or screw capped tubes (liquid media) and stored at $4^{\circ} \mathrm{C}$ in well closed plastic bags and used within one week.

\section{Prepared culture media}

Soft nutrient agar and LB broth were prepared by dissolving (or suspending) the calculated amount of ingredients in distilled water and the total volume was completed by distilled water to $1 \mathrm{~L}$ then sterilized by autoclaving at $121^{\circ} \mathrm{C}$ for $15 \mathrm{~min}$, distributed in sterile screw capped vials or flasks, respectively, and stored at $4^{\circ} \mathrm{C}$ in well closed plastic bags and used within one week [21].

\section{Determination of minimum inhibitory concentrations (MICs) of antibiotics and non-antibiotics against different bacterial isolates}

The MICs of the tested agents against all isolates were determined by agar dilution method according to the procedure described by [22]. Muller-Hinton agar (MHA) was used as a basal medium. Membrane filtered stock solution of each tested antimicrobial agent was prepared. Also, membrane filtered stock solution $(1000 \mu \mathrm{g} / \mathrm{ml})$ of each tested drugs was prepared. The selected antimicrobial agent was added at increasing concentrations (multiple of two, i.e.; 0, 0.5, 1, 2, 4 ..... 1024 $\mu \mathrm{g} \mathrm{ml}^{-1}$ ) in the molten MHA and poured into petri dishes. Tested drug was added at final concentrations of 0 (control), 5, 10, 25, 50, 100, 200, $400,600,800$ and $1000 \mu \mathrm{g} / \mathrm{ml}$ in the molten MHA and poured into sterile Petri dishes.

\section{Effect of the tested drugs on growth of the tested bacterial isolates}

The influence of antihistaminic drugs on the growth of MDR clinical isolates of K. pneumoniae, was studied by a spectrophotmoetric method, described by $[23,24]$. Flasks containing $30 \mathrm{ml}$ nutrient broth $(\mathrm{NB})$ were inoculated with overnight $\mathrm{NB}$ cultures of the tested microorganisms and diluted to give $106 \mathrm{CFU} / \mathrm{ml}$. Each drug was added, separately, to the inoculated flasks to obtain a final concentration of 0(control), 1, 10 or $100 \mu \mathrm{g} / \mathrm{ml}$. All flasks were incubated in the shaking incubator at $90 \mathrm{rpm}$ at $37^{\circ} \mathrm{C}$. A sample of $4 \mathrm{ml}$ was withdrawn from each flask at $0,2,4,6,8$ and 24 hrs time intervals. The optical density (OD) of each sample was measured at $620 \mathrm{~nm}$ using SCHIMADZUU spectrophotometer. Growth curves were constructed by plotting log OD620 against sampling time (hrs).

Investigation of the effect of drugs / antimicrobial agent's combinations against MDR isolates

Determination of MIC of tested drugs /antimicrobial agent's combinations against MDR isolates: MIC of tested drugs / antimicrobial agent's combinations against selected MDR isolates 
was determined by agar dilution method according to the procedure described by $[22,25]$. The tested drug solution was added, to a final concentration of 1,10 , or $100 \mu \mathrm{g} / \mathrm{ml}$, to the basal medium containing increasing concentrations (multiple of two, i.e... 0.5, 1, 2, 4 .... 1024 $\mu \mathrm{g} / \mathrm{ml}$ ) of the selected antimicrobial agents. Plates containing an identical amount of the basal medium, but free from the combination of antimicrobial agents with tested drugs, and plates containing antimicrobials only were prepared and used as control.

After (16-24) hrs of incubation at $37^{\circ} \mathrm{C}$, the lowest concentration of each antibiotic either in combination with each of the tested drug, which showed no visible growth was regarded as the MIC value.

\section{Calculation of fractional inhibitory concentration (FIC) [26-28]:}

The fractional inhibitory concentration (FIC) was used to interpret the results of agar dilution method and calculated as follows; FIC of drug A = MIC of drug A in combination with tested drugs / MIC of drug A alone. The interaction was recorded as synergism (S) when FIC $=0.5$, indifference $(\mathrm{I})$ when FIC $>0.5-4$, and antagonism $(\mathrm{A})$ when FIC $>4$.

\section{Confirmation of synergism or antagonism between the tested drugs and antimicrobial agents using efficiency of plating (EOP) test}

The method was described according to [29]. Three groups of nutrient agar plates were prepared as follows: a) the first group: nutrient agar plates containing 1,10 , and $100 \mu \mathrm{g} / \mathrm{ml}$ of each tested drug. b) The second group: nutrient agar plates containing combination of $1 / 4 \mathrm{MIC}$ of the antimicrobial agent and 1,10 or $100 \mu \mathrm{g} / \mathrm{ml}$ of each tested drug. c) The third group: control nutrient agar plates that lack both antimicrobial agents and tested drugs. The tested bacterial isolates were grown overnight at $37^{\circ} \mathrm{C}$ in nutrient broth. Cultures were diluted with sterile saline and used to inoculate $2.5 \mathrm{ml}$ top nutrient agar layer on each previously prepared groups of nutrient agar plates. The plates were incubated at $37^{\circ} \mathrm{C}$ for at least $24 \mathrm{hrs}$. Viable counts were reported and EOP was calculated as the number of colonies appearing on each test plate divided by the number of colonies appearing on the control plate. For each combination, log EOP was plotted versus the concentration of the tested drug.

\section{Investigation of possible physical interaction between tested drugs and different antimicrobial agents using electronic absorption spectrophotometric method}

The method described by $[30,31]$ was applied. The electronic absorption spectra of aqueous solutions of tested drugs, aqueous solution of some antimicrobial agents and a combination containing equimolar concentration of each agent were determined in the range of $200-400 \mathrm{~nm}$ on SCHIMADZU UV/ Vis Spectrophotometer. The data obtained from the spectra of each individual agent were used to calculate the spectrum of combination. The calculated spectrum was compared to the experimentally obtained one.

\section{Effect of the tested drugs on the morphology of reference bacterial strains}

\section{Using Gram's staining technique}

Reference strain of $\mathrm{K}$. pneumoniae was grown in NB broth at $37^{\circ} \mathrm{C}$ in absence and presence of different concentrations of the tested drugs.
Samples of drug-treated and untreated cultures of each bacterial species were subjected to Gram's staining technique, and then examined under the oil immersion lens. Microscopical pictures were taken using digital camera.

\section{Using Electron microscope examination}

Reference strain of K. pneumoniae that showed morphological changes upon treatment with tested drugs were subjected to electron microscopic examination. The procedures were carried out according $[32,33]$. The procedures were performed in the electron microscope unit, Faculty of medicine, Tanta University, Egypt.

\section{Effect of the tested drugs on the bacterial adhesion and biofilm production}

This effect was investigated using a crystal violet assay as described by $[34,35]$. Overnight cultures of $\mathrm{K}$ pneumoniae (K33) isolate in $2 \mathrm{ml}$ of trypticase soy broth (TSB) were diluted with fresh TSB and standardized to contain $106 \mathrm{CFU} / \mathrm{ml}$. Aliquots $(2 \mathrm{ml})$ of the diluted culture were added to polypropylene tubes. The concentrations of tested drug were adjusted to be 0 (control), 1,10 and $100 \mu \mathrm{g} / \mathrm{ml}$. After overnight incubation at $37^{\circ} \mathrm{C}$, the contents of the tubes were gently aspirated, using Pasteur pipette connected to low vacuum, The tubes were then washed 4 times with sterile PBS ( $\mathrm{pH} 7.2$ ) to eliminate the unbound bacteria. Adherent organisms were fixed overnight with Bouin's fixative solution. The fixative solution was removed by washing the tubes 3-4 times with $50 \%$ ethanol. The tubes were stained by $0.1 \%$ $(\mathrm{w} / \mathrm{v})$ crystal violet. By placing the tubes under running distilled water, the excess stain was removed, and the tubes were air dried. Color intensity of the tested tubes was compared visually to that of the control and the tubes were photographed. Biofilm formation was considered positive when a visible film lined the wall and the bottom of the tube. The scoring for tube method was done visually according to the results of the control. The biofilm formed was scored as l-weak/none, 2 -moderate and 3-high/strong according to $[35,36]$. The dye attached to cells was dissolved in $1.5 \mathrm{ml}$ of $33 \%$ glacial acetic acid and, a volume of $200 \mu \mathrm{l}$ from each tube was transferred to its corresponding well of tissue culture plate. Optical density (OD) of each tube was determined at $570 \mathrm{~nm}$. The blank was determined by measuring OD of tube filled with PBS and positive control was determined by measuring OD of tube with pure culture.

\section{Effect of the tested drugs on the NPN efflux by K pneumoniae}

1-N-phenylnaphthylamine (NPN) is an uncharged lipophilic molecule, represents hydrophobic antimicrobials such as quinolones, which fluoresces weakly in aqueous environments such as that of the lipid bilayers of biological membranes [37]. The method reported by [38] for NPN efflux assays was followed. Quinolone resistant isolates were selected and grown in $\mathrm{LB}$ broth overnight at $37^{\circ} \mathrm{C}$ in a shaking incubator. Cells were harvested, washed with HEPES- $\mathrm{MgCl}_{2}$ buffer $(\mathrm{pH}$ 7.2) and centrifuged at $4000 \mathrm{rpm}$ for $10 \mathrm{~min}$. The pellets were resuspended in HEPES-glucose buffer ( $\mathrm{pH} \mathrm{7.2)} \mathrm{and} \mathrm{diluted} \mathrm{to} \mathrm{give} \mathrm{an} \mathrm{optical} \mathrm{density} \mathrm{of} 0.5$ at $620 \mathrm{~nm}$. These steps were applied for each isolate grown in absence and presence of $100 \mu \mathrm{g} / \mathrm{ml}$ tested drug. Ten microliters of NPN ( $5 \mathrm{mM})$ were added. Recording results started at $0,1,2,3,4,5$ and $6 \mathrm{~min}$. An aliquot of $10 \mu \mathrm{l}$ of CCCP (efflux pump inhibitor) was added to each isolate either treated or untreated with tested drug, left for 15 minutes then $10 \mu \mathrm{l}$ of NPN ( $5 \mathrm{mM}$ ) were added results recorded at $0,1,2,3,4,5$, and 6 min. time intervals. The fluorescence measurements were performed using SCHIMADZUU spectrofluorometer with an excitation $\lambda$ of $350 \mathrm{~nm}$ and an emission $\lambda$ of 
Citation: El-Banna TES, Sonbol FI, El-Aziz AAA, Al-Fakharany OM (2016) Modulation of Antibiotic Efficacy against Klebsiella pneumoniae by Antihistaminic Drugs. J Med Microb Diagn 5: 225. doi:10.4172/2161-0703.1000225

Page 4 of 13

$420 \mathrm{~nm}$. All assays were performed at room temperature. The average of 3 fluorescence values was taken each min for 6 minutes, before and after addition of CCCP

\section{Results}

In the present work, the susceptibility of $50 \mathrm{~K}$. pneumoniae isolates to each of 16 antimicrobial agents was determined by agar dilution method. Isolates were grouped into resistant (R), intermediate (I) or sensitive (S) according to CLSI 2010. Resistant isolates showed MICs values $\geq$ break-point concentration of each antibacterial agent. The antimicrobial resistance patterns of these isolates were presented in order to specify multidrug resistant (MDR) isolates, as shown in (Table 1). Multiresistance was considered on the basis that the studied clinical isolates were resistant to antibiotics belonging to at least 3 classes and up to all tested antibiotics. Thirty MDR isolates of $K$. pneumoniae representing different resistance patterns were selected for further studies. Whereas the standard strain used was selected so that it was sensitive to the tested antibiotics. MICs values of tested antimicrobial agents against the selected MDR isolates were determined by agar dilution method.

The bacteriostatic activity of the antihistaminics under study was investigated through MIC determination against both the tested reference K. pneumoniae strain as well as the selected MDR clinical isolates using agar dilution technique. Both the standard strain and the multiresistant isolates showed similar responses to the action of the antihistaminics. It was observed that the reference K. pneumoniae strain was insensitive to all of the tested drugs at the studied concentration range as indicated by MICs values more than $1000 \mu \mathrm{g} / \mathrm{ml}$ except for cyoproheptadine MIC value was $400 \mu \mathrm{g} / \mathrm{ml}$ and promethazine MIC value was $600 \mu \mathrm{g} / \mathrm{ml}$. Also, cyproheptadine and promethazine showed moderate antimicrobial activity against the tested MDR isolates. The MIC values ranged from $400-800 \mu \mathrm{g} / \mathrm{ml}$, against $22(73 \%)$ isolates and $20(67 \%)$ isolates out of 30 MDR K. pneumoniae, respectively. These drugs were selected for further studies.

\section{Effect of selected non-antibiotic drugs on bacterial growth}

One representative K. pneumoniae isolate from those showing least MIC values was chosen for testing the effect of non-antibiotic drugs on bacterial growth. The tested stains were grown in the absence and presence non-antibiotic drugs (cyproheptadine and promethazine). Optical density (OD620) values at each time interval were measured and Log OD620 values were calculated. Growth curves were constructed by blotting log OD620 versus time representing the effect of different concentrations of tested drugs on bacterial growth as shown in Figures 1 and 2.

\section{Investigation of the effect of drugs / antibiotics combinations on MDR isolates}

\section{Effect of tested drugs on antibiotics efficacy}

Percentages of synergism (S) and antagonism (A) were presented in Table 2. Significant synergistic or antagonistic combinations were considered when its incidence was $\geq 50 \%$ of the tested MDR isolates.

\begin{tabular}{|c|c|c|c|}
\hline \multicolumn{4}{|c|}{ Antimicrobial resistance patterns } \\
\hline Pattern code & Resistance marker & $\begin{array}{l}\text { Pattern } \\
\text { incidence }\end{array}$ & $\begin{array}{l}\text { Selected MDR } \\
\text { isolates }\end{array}$ \\
\hline KI & AMP-AMX-CN-CM & 1 & - \\
\hline K II & AMP-AMX-CN-CEF-CTX-CM & 1 & - \\
\hline K III & AMP-AMX-CN-CTX-ERY-AZI-STR-CM-OFX & 2 & K11 \\
\hline K IV a & AMP-AMX-CEF-ERY-AZI-AK-GN-STR-CM-OFX & 2 & K8 \\
\hline $\mathrm{K} \mathrm{IV} \mathrm{b}$ & AMP-AMX-CN-ERY-AZI-AK-GN-STR-CM-OFX & 1 & K7 \\
\hline K IV c & AMP-AMX-CN-CEF-CTX-OXT-ERY-AZI-CM-OFX & 3 & K14 \\
\hline K IV d & AMP-AMX-CN-OXT-ERY-AK-GN-STR-CM-OFX & 2 & K23 \\
\hline KIV e & AMP-AMX-CN-CEF-CTX-ERY-AZI-STR-CM-OFX & 1 & K6 \\
\hline $\mathrm{K} \vee \mathrm{a}$ & AMP-AMX-CN-CEF-CTX-ERY-AZI-AK-STR-CM-OFX & 3 & K10 \\
\hline$K \vee b$ & AMP-AMX-CN-CTX-OXT-ERY-AZI-AK-GN-CM-OFX & 1 & K12 \\
\hline $\mathrm{KV} \mathrm{c}$ & AMP-AMX-CN-CEF-OXT-ERY-AZI-AK-GN-STR-CM & 2 & K33 \\
\hline $\mathrm{KV} d$ & AMP-AMX-CN-CEF-ERY-AK-GN-STR-CM-OFX-CIP & 2 & K40 \\
\hline $\mathrm{K} \mathrm{VI} \mathrm{a}$ & AMP-AMX-CN-CEF-CTX-OXT-ERY-AZI-AK-GN-STR-CM & 1 & K27 \\
\hline K VI b & AMP-AMX-CN-CTX-ERY-AK-GN-STR-CM-OFX-LEV-CIP & 2 & K18 \\
\hline K VI c & AMP-AMX-CN-CEF-CTX-OXT-ERY-AZI-AK-GN-STR-CM-OFX & 2 & K43 \\
\hline \multirow[b]{2}{*}{ KVII a } & AMP-AMX-CN-CEF-CTX-OXT-ERY-AZI-STR-CM-OFX-LEV-CIP & 3 & K4 \\
\hline & AMP-AMX-CEF-CTX-OXT-ERY-E-AZI-AK-GN-STR-CM-OFX-CIP & & \\
\hline KVII b & AMP-AMX-CN-CTX-ERY-AZI-AK-GN-STR-CM-OFX-LEV-CIP & 2 & $\mathrm{~K} 15, \mathrm{~K} 31$ \\
\hline KVII c & AMP-AMX-CN-CEF-CTX-OXT-ERY-AZI-AK-GN-STR-CM-OFX & 3 & K21, K25 \\
\hline KVII d & & 1 & K38, K5 \\
\hline \multirow[b]{2}{*}{ KVIII a } & AMP-AMX-CEF-CTX-OXT-ERY-AZI-AK-GN-STR-CM-OFX-LEV-CIP & 2 & $\mathrm{~K} 16, \mathrm{~K} 48$ \\
\hline & AMP-AMX-CN-CEF-CTX-OXT-ERY-AZI-AK-GN-STR-CM-OFX-CIP & & \\
\hline KVIII b & AMP-AMX-CN-CEF-CTX- OXT-ERY-AZI-AK -STR-CM-OFX-LEV-CIP & 4 & K28, K17 \\
\hline KVIII c & & 3 & $\mathrm{~K} 19, \mathrm{~K} 22$ \\
\hline K IX & AMP-AMX-CN-CEF-CTX- OXT-ERY-AZI-AK -GN -STR-CM-OFX-LEV-CIP & 3 & $\mathrm{~K} 39, \mathrm{~K} 50$ \\
\hline $\mathrm{KX}$ & AMP-AMX-CN-CEF-CTX- OXT-ERY-AZI-AK -GN -STR-CM-OFX-LEV-CIP-MOX & 3 & K3, K24 \\
\hline
\end{tabular}

AMP; Ampicillin, AMX; Amoxacillin, CN; Cephalexine, CEF; Cefaclor, CTX; Cefotaxime, OXT; Oxytetracycline, ERY; Erythromycin, AZI; Azithromycin, AK; Amikacin, GN; Gentamycin, STR; Streptomycin, CM; Chloramphenicol, OFX; Ofloxacin, LEV; Levofloxacin, CIP; Ciprofloxacin, MOX; Moxifloxacin.

Table 1: Multiple antibiotic resistance (MAR) indexes and antimicrobial resistance patterns of $K$. pneumoniae isolates. 


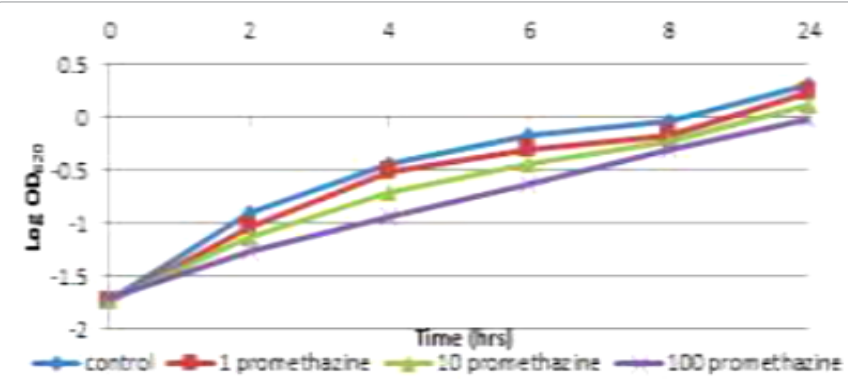

Figure 1: Growth curve of MDR isolate (K11) in the absence and presence of $1,10,100 \mu \mathrm{g} / \mathrm{ml}$ promethazine.

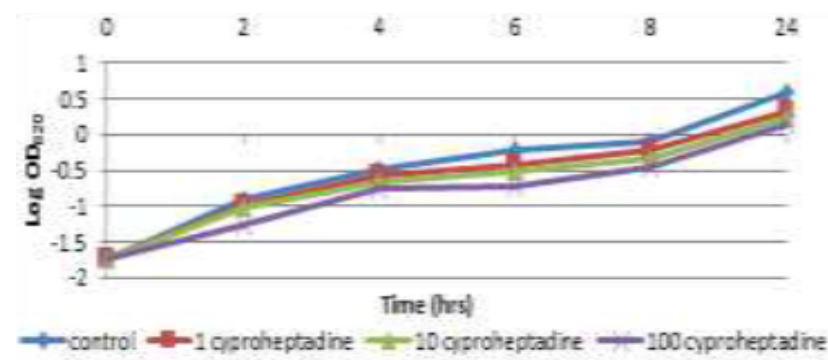

Figure 2: Growth curve of MDR isolate (K14) in the absence and presence of $1,10,100 \mu \mathrm{g} / \mathrm{ml}$ cyproheptadine.

As observed in the following table bolded values referred to significant synergistic or antagonistic combinations.

It was found that, although indifferent effects were prevalent in case of most drugs / antibiotics combinations. Siginificant synergism was observed in case of most tested drugs' combinations with macrolides except for cetrizine and dimenhydrinate. Furthermore, combinations of diphenhydramine, dimenhydrinate or cetirizine with amikacin or gentamicin showed synergistic effects and the effect varied according to drug concentration.

As shown in Table 2, marked synergism was detected in case of triprolidine $(100 \mu \mathrm{g} / \mathrm{ml})$ combination with azithromycin $(80 \%)$ and in case of diphenhydramine $(100 \mu \mathrm{g} / \mathrm{ml})$ combination with amikacin (90\%). In addition, it was observed that non-significant antagonistic interactions $(<50 \%$ incidence) were recorded in case of all tested drugs / antibiotics combinations. Furthermore, it was observed that among 112 combinations, only 19 significant ( $\geq 50 \%$ incidence) synergistic combinations were recorded for $K$. pneumoniae. One synergistic combination was chosen on the basis of highest incidence for selection of combination and lowest FIC for selection of bacterial isolate. This combination was triprolidine / azithromycin against K. pneumoniae (K8) isolate. The selected representative synergistic combination was chosen for further confirmation using the Efficiency of plating (EOP) test.

Evaluation of synergistic activity using efficiency of plating (EOP) test

Synergistic effect of the selected combination was confirmed by EOP test. It was observed that log EOP values decreased by increasing drug concentration confirming synergism as shown in Figure 3.

Investigation of possible interactions between drugs and different antimicrobial agents

Investigation of possible physical interaction between selected drugs and different antimicrobial agents using electronic absorption spectrophotometric method

For combinations showing a synergistic effect, experimental studies were carried out using electronic absorption spectrometry in order to determine whether there is some sort of physical interaction or not. The electronic absorption spectra of each drug, antibiotic and a combination of both were determined in the wavelength range $200-400 \mathrm{~nm}$. The data obtained from the spectra of the prepared solutions of the tested drug or antibiotic were used to calculate the spectrum of their combination. The calculated spectra were compared to the experimentally obtained ones. As shown in Figures 4 and 5, it was observed that the calculated spectra differed from the experimentally obtained spectra suggesting some sort of interaction or ionic association.

Effect of tested drugs on some bacterial virulence factors and resistance mechanisms

The effect of the tested drugs on bacterial biofilm production was investigated both qualitatively using crystal violet assay method and quantitatively by spectrophotometer assay.

\section{Qualitative determination of the effect of the tested drugs on bacterial biofilm production}

The tested MDR isolates were screened for adhesion to plastic surface and hence biofilm production by crystal violet assay. The highest biofilm producer was K. pneumoniae (K33) isolate. The effect of the tested drugs on bacterial biofilm production by this isolate was qualitatively determined using simple tube method. Reduction in biofilm production by bacterial isolate treated with different concentrations of tested drugs was observed visually as shown in Figure 6. The ability of this isolate to produce biofilm was diminished in a concentration dependant manner when exposed to different concentrations of these drugs as shown in Table 3.

\section{Quantitative determination of the effect of the tested drugs on bacterial biofilm production}

Stained adhered biofilm attached to each tube was extracted by 1.5 $\mathrm{ml}$ of $33 \%$ glacial acetic acid. A volume of $200 \mu \mathrm{l}$ from each tube was filled in its corresponding well of tissue culture plate and this process was repeated in triplicate. Optical density (OD) of each well content was measured by using micro ELISA auto reader at wavelength 570 $\mathrm{nm}$. The mean OD values were calculated. The obtained results were presented as shown in Table 4. Marked reduction in biofilm production was observed after treating with promethazine. The decrease in biofilm production was directly proportional to drug concentration as shown in Figure 7.

\section{Effect of tested drugs on bacterial efflux mechanisms}

The effect of the tested drugs on bacterial efflux mechanisms was also investigated. Quinolone resistant K. pneumoniae (K6) isolate was selected to study the effect of tested drugs on bacterial efflux mechanism. The efflux of NPN by this isolate was determined by measurement of fluorescence along 6 minutes for untreated cells (control) and overnight drug treated cells. It was observed that promethazine, cyproheptadine and diphenhydramine had marked effect on the NPN efflux by the tested isolate (Figure 8). The fluorescence values after addition of NPN were decreased indicating the efflux of NPN by this isolate. Treating of K. pneumoniae (K6) isolate with the efflux inhibitor CCCP resulted in increasing fluorescence compared to untreated cells. Overnight treating bacterial cells with these drugs lead to increase in fluorescence 
Citation: El-Banna TES, Sonbol FI, El-Aziz AAA, Al-Fakharany OM (2016) Modulation of Antibiotic Efficacy against Klebsiella pneumoniae by Antihistaminic Drugs. J Med Microb Diagn 5: 225. doi:10.4172/2161-0703.1000225

Page 6 of 13

(a)

\begin{tabular}{|c|c|c|c|c|c|c|c|c|c|c|c|c|c|c|c|c|c|c|}
\hline \multirow{3}{*}{ AMA } & \multicolumn{6}{|c|}{ Promethazine $(\mu \mathrm{g} / \mathrm{ml})$} & \multicolumn{6}{|c|}{ Cetrizine $(\mu \mathrm{g} / \mathrm{ml})$} & \multicolumn{6}{|c|}{ Diphenhydramine $(\mu \mathrm{g} / \mathrm{ml})$} \\
\hline & \multicolumn{2}{|l|}{1} & \multicolumn{2}{|l|}{10} & \multicolumn{2}{|l|}{100} & \multicolumn{2}{|l|}{1} & \multicolumn{2}{|l|}{10} & \multicolumn{2}{|l|}{100} & \multicolumn{2}{|l|}{1} & \multicolumn{2}{|l|}{10} & \multicolumn{2}{|l|}{100} \\
\hline & $\% A$ & $\% \mathbf{S}$ & $\% A$ & $\% \mathbf{S}$ & $\% A$ & $\% \mathbf{S}$ & $\% A$ & $\% S$ & $\% A$ & $\% \mathrm{~S}$ & $\% A$ & $\% \mathrm{~S}$ & $\% A$ & $\% \mathrm{~S}$ & $\% A$ & $\% \mathrm{~S}$ & $\% A$ & $\% \mathrm{~S}$ \\
\hline AMP & 0 & 0 & 0 & 0 & 0 & 0 & 0 & 0 & 0 & 0 & 0 & 0 & 0 & 0 & 0 & 0 & 0 & 10 \\
\hline AMX & 0 & 0 & 0 & 0 & 0 & 0 & 0 & 0 & 0 & 0 & 0 & 0 & 0 & 0 & 0 & 0 & 0 & 20 \\
\hline $\mathrm{CN}$ & 0 & 0 & 0 & 0 & 0 & 0 & 0 & 0 & 0 & 0 & 0 & 0 & 0 & 0 & 0 & 0 & 0 & 0 \\
\hline CEF & 0 & 7 & 0 & 20 & 0 & 20 & 0 & 0 & 0 & 20 & 0 & 20 & 0 & 0 & 0 & 0 & 0 & 0 \\
\hline CTX & 0 & 27 & 0 & 40 & 0 & 47 & 0 & 30 & 0 & 50 & 0 & 80 & 0 & 0 & 0 & 0 & 0 & 10 \\
\hline OXT & 0 & 0 & 0 & 0 & 0 & 0 & 0 & 0 & 0 & 0 & 0 & 0 & 0 & 0 & 0 & 0 & 0 & 0 \\
\hline ERY & 0 & 10 & 0 & 43 & 0 & 40 & 0 & 17 & 0 & 17 & 0 & 20 & 0 & 40 & 0 & 40 & 0 & 60 \\
\hline AZI & 0 & 47 & 0 & 47 & 0 & 50 & 0 & 40 & 0 & 40 & 0 & 40 & 0 & 30 & 0 & 40 & 0 & 50 \\
\hline AK & 0 & 20 & 0 & 40 & 0 & 40 & 0 & 30 & 0 & 50 & 0 & 60 & 0 & 43 & 0 & 90 & 0 & 90 \\
\hline GN & 0 & 40 & 0 & 40 & 20 & 47 & 0 & 7 & 0 & 20 & 0 & 20 & 0 & 37 & 0 & 70 & 20 & 70 \\
\hline STR & 0 & 30 & 0 & 40 & 0 & 40 & 0 & 0 & 0 & 0 & 0 & 20 & 3 & 0 & 10 & 20 & 10 & 30 \\
\hline $\mathrm{CM}$ & 0 & 0 & 0 & 0 & 0 & 0 & 0 & 0 & 0 & 0 & 0 & 0 & 0 & 0 & 0 & 20 & 0 & 30 \\
\hline OFX & 0 & 0 & 0 & 0 & 0 & 10 & 20 & 0 & 10 & 0 & 10 & 0 & 0 & 10 & 0 & 30 & 0 & 20 \\
\hline LEV & 0 & 20 & 0 & 30 & 0 & 20 & 10 & 0 & 10 & 20 & 30 & 20 & 0 & 30 & 0 & 40 & 0 & 40 \\
\hline CIP & 0 & 30 & 0 & 30 & 0 & 60 & 0 & 10 & 7 & 10 & 10 & 20 & 0 & 40 & 0 & 60 & 0 & 60 \\
\hline MOX & 0 & 0 & 0 & 20 & 0 & 30 & 0 & 17 & 0 & 30 & 0 & 40 & 0 & 10 & 0 & 40 & 0 & 40 \\
\hline
\end{tabular}

(b)

\section{\begin{tabular}{|l|l|l} 
Chlorepheniramine $(\mu \mathrm{g} / \mathrm{ml})$ & Triprolidine $(\mu \mathrm{g} / \mathrm{ml})$ & Dimenhydrinate $(\mu \mathrm{g} / \mathrm{ml})$
\end{tabular}}

\begin{tabular}{|c|c|c|c|c|c|c|c|c|c|c|c|c|c|c|c|c|c|c|}
\hline \multirow{2}{*}{ AMA } & \multicolumn{2}{|l|}{1} & \multicolumn{2}{|l|}{10} & \multicolumn{2}{|l|}{100} & \multicolumn{2}{|l|}{1} & \multicolumn{2}{|l|}{10} & \multicolumn{2}{|l|}{100} & \multicolumn{2}{|l|}{1} & \multicolumn{2}{|l|}{10} & \multicolumn{2}{|l|}{100} \\
\hline & $\% A$ & $\% S$ & $\% A$ & $\% S$ & $\% A$ & $\% \mathrm{~S}$ & $\% A$ & $\% S$ & $\% A$ & $\% S$ & $\% A$ & $\% \mathrm{~S}$ & $\% A$ & $\% S$ & $\% A$ & $\% \mathrm{~S}$ & $\% A$ & $\% \mathrm{~S}$ \\
\hline AMP & 0 & 0 & 0 & 0 & 0 & 0 & 0 & 0 & 0 & 0 & 0 & 0 & 0 & 0 & 0 & 0 & 0 & 0 \\
\hline AMX & 0 & 0 & 0 & 0 & 0 & 0 & 0 & 0 & 0 & 0 & 0 & 0 & 0 & 0 & 0 & 0 & 0 & 0 \\
\hline $\mathrm{CN}$ & 0 & 0 & 0 & 0 & 0 & 0 & 0 & 0 & 0 & 0 & 0 & 0 & 0 & 0 & 0 & 0 & 0 & 0 \\
\hline CEF & 0 & 0 & 0 & 0 & 0 & 0 & 0 & 0 & 0 & 10 & 0 & 20 & 0 & 0 & 0 & 10 & 0 & 10 \\
\hline CTX & 0 & 0 & 0 & 10 & 0 & 10 & 0 & 0 & 0 & 10 & 0 & 30 & 0 & 30 & 0 & 30 & 0 & 40 \\
\hline OXT & 0 & 0 & 0 & 0 & 0 & 0 & 0 & 0 & 0 & 0 & 0 & 0 & 0 & 0 & 0 & 0 & 0 & 0 \\
\hline ERY & 0 & 20 & 0 & 20 & 0 & 40 & 0 & 0 & 0 & 30 & 0 & 20 & 0 & 0 & 0 & 0 & 0 & 20 \\
\hline AZI & 0 & 20 & 0 & 50 & 0 & 60 & 0 & 40 & 0 & 70 & 0 & 80 & 0 & 0 & 0 & 20 & 0 & 30 \\
\hline AK & 0 & 10 & 10 & 40 & 10 & 30 & 17 & 20 & 40 & 40 & 40 & 30 & 0 & 37 & 0 & 60 & 0 & 80 \\
\hline GN & 0 & 0 & 20 & 30 & 0 & 40 & 0 & 7 & 0 & 20 & 0 & 20 & 0 & 30 & 0 & 30 & 10 & 40 \\
\hline STR & 0 & 0 & 0 & 0 & 0 & 0 & 0 & 0 & 0 & 0 & 0 & 10 & 0 & 0 & 0 & 0 & 0 & 10 \\
\hline CM & 0 & 0 & 0 & 0 & 0 & 0 & 0 & 0 & 0 & 0 & 0 & 0 & 0 & 0 & 0 & 0 & 0 & 0 \\
\hline OFX & 0 & 0 & 0 & 0 & 0 & 0 & 0 & 10 & 0 & 0 & 0 & 0 & 0 & 0 & 0 & 0 & 0 & 0 \\
\hline LEV & 0 & 0 & 0 & 0 & 0 & 0 & 7 & 0 & 20 & 10 & 0 & 10 & 10 & 0 & 0 & 10 & 10 & 10 \\
\hline CIP & 0 & 0 & 0 & 0 & 0 & 0 & 0 & 0 & 0 & 0 & 0 & 0 & 0 & 0 & 0 & 0 & 0 & 0 \\
\hline MOX & 0 & 0 & 0 & 0 & 0 & 0 & 0 & 0 & 0 & 0 & 0 & 0 & 0 & 0 & 0 & 0 & 0 & 0 \\
\hline
\end{tabular}

AMA; Antimicrobial agent, AMP; Ampicillin, AMX; Amoxacillin, CN; Cephalexine, CEF; Cefaclor, CTX; Cefotaxime, OXT; Oxytetracycline, ERY; Erythromycin, AZI;

Azithromycin, AK; Amikacin, GN; Gentamicin, STR; Streptomycin, CM; Chloramphenicol, OFX; Ofloxacin, LEV; Levofloxacin, CIP; Ciprofloxacin, MOX; Moxifloxacin. A; Antagonism (FIC > 4), S; Synergism ( $F I C \leq 0.5)$.

(c)

AMA

\begin{tabular}{|c|c|c|c|}
\hline \multirow[t]{3}{*}{ AMA } & & & \\
\hline & \multicolumn{2}{|l|}{1} & 10 \\
\hline & $\% A$ & $\% \mathrm{~S}$ & $\% A$ \\
\hline AMP & 0 & 0 & 0 \\
\hline AMX & 0 & 0 & 0 \\
\hline $\mathrm{CN}$ & 0 & 0 & 0 \\
\hline CEF & 0 & 0 & 0 \\
\hline CTX & 0 & 20 & 0 \\
\hline OXT & 0 & 0 & 0 \\
\hline
\end{tabular}

Cyproheptadine $(\mu \mathrm{g} / \mathrm{ml})$

\begin{tabular}{|l|l|l|}
\hline \multicolumn{1}{|c|}{} & $\mathbf{1 0 0}$ & \\
\hline \%S & \%A & \%S \\
\hline 0 & 0 & 0 \\
\hline 0 & 0 & 0 \\
\hline 0 & 0 & 0 \\
\hline 10 & 0 & 20 \\
\hline 50 & 0 & 40 \\
\hline 0 & 0 & 0 \\
\hline
\end{tabular}


Citation: El-Banna TES, Sonbol FI, El-Aziz AAA, Al-Fakharany OM (2016) Modulation of Antibiotic Efficacy against Klebsiella pneumoniae by Antihistaminic Drugs. J Med Microb Diagn 5: 225. doi:10.4172/2161-0703.1000225

Page 7 of 13

\begin{tabular}{|c|c|c|c|c|c|c|}
\hline ERY & 0 & 30 & 0 & 30 & 0 & 40 \\
\hline AZI & 0 & 30 & 0 & 50 & 0 & 60 \\
\hline AK & 0 & 20 & 0 & 20 & 0 & 30 \\
\hline GN & 0 & 0 & 0 & 20 & 20 & 40 \\
\hline STR & 0 & 0 & 0 & 0 & 0 & 0 \\
\hline $\mathrm{CM}$ & 0 & 0 & 0 & 10 & 0 & 30 \\
\hline OFX & 0 & 0 & 0 & 0 & 0 & 0 \\
\hline LEV & 10 & 0 & 20 & 0 & 20 & 0 \\
\hline CIP & 0 & 0 & 10 & 0 & 10 & 20 \\
\hline MOX & 0 & 10 & 0 & 20 & 0 & 30 \\
\hline
\end{tabular}

AMA; Antimicrobial agent, AMP; Ampicillin, AMX; Amoxacillin, CN; Cephalexine, CEF; Cefaclor, CTX; Cefotaxime, OXT; Oxytetracycline, ERY; Erythromycin, AZI; Azithromycin, AK; Amikacin, GN; Gentamicin, STR; Streptomycin, CM; Chloramphenicol, OFX; Ofloxacin, LEV; Levofloxacin, CIP; Ciprofloxacin, MOX; Moxifloxacin. A; Antagonism (FIC > 4), S; Synergism ( $F I C \leq 0.5)$.

Table 2: (a-c) Percentages of synergism and antagonism of tested drugs $/$ antimicrobial agents combinations against $K$. pneumoniae isolates $(n=30)$.

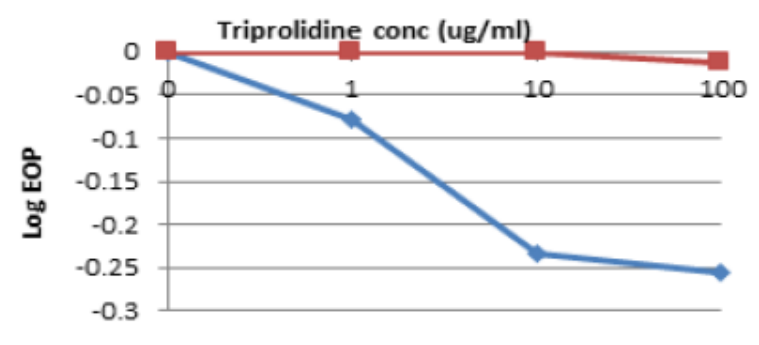

-triprolidine + azithromycin - triprolidine

Figure 3: EOP test of $\mathrm{K}$. pneumoniae $(\mathrm{k} 8)$ isolate in the absence and presence of $128 \mu \mathrm{g} / \mathrm{ml}$ of azithromycin per $\mathrm{ml}$ as a function of triprolidine concentration.

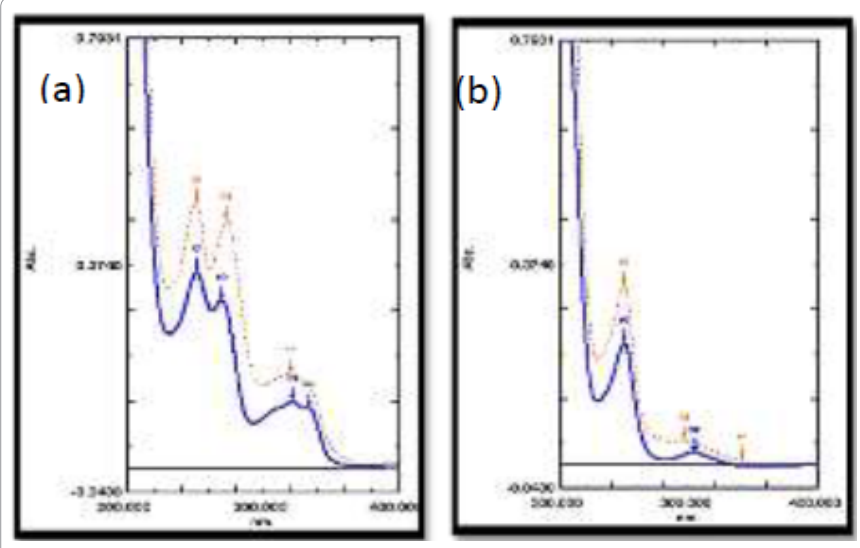

Figure 4: The electronic absorption spectra of: (a) promethazine and ciprofloxacin $\mathrm{HCl}$ combination. (b) promethazine and gentamicin sulfate combination. Calculated spectrum: Experimentally obtained spectrum.

values and also enhancement of CCCP action suggesting inhibition of efflux pumps as shown in Figure 9.

Effect of tested drugs on bacterial morphology: Reference strain of K. pneumoniae (K13883) was grown in the absence and presence of different concentrations of the tested drugs. Samples of drug treated and untreated cultures were stained and examined microscopically. Changes of morphological characters were observed in case of K. pneumoniae reference strain treated with chlorpheniramine. Gram's stained films of K. pneumoniae cells treated with $100 \mu \mathrm{g} / \mathrm{ml}$ chlorpheniramine as well as untreated cells were examined microscopically as presented in Figure
10. K. pneumoniae cells treated with $100 \mu \mathrm{g} / \mathrm{ml}$ chlorpheniramine as well as untreated cells were also examined using transmission electron microscope. It was observed that treated cells showed filamentation due septum formation without separation of cells as shown in Figure 11 .

\section{Discussion}

In the present study, the antimicrobial activity of seven antihistaminic drugs belonging to both old and new generations were investigated using both standard bacterial strain and multidrug resistant clinical isolates of $K$. pneumoniae. It was found that the tested phenothiazine antihistaminic, promethazine, and cyproheptadine were the most effective among the studied antihistaminics. They exhibited high in vitro antibacterial action with MIC values ranging from 600 $1000 \mu \mathrm{g} / \mathrm{ml}$ against MDR K. pneumoniae isolates. Other tested drugs lacked activity against both tested standard bacterial strains and multidrug resistant (MDR) clinical isolates as indicated by MIC values $>1000 \mu \mathrm{g} / \mathrm{ml}$.

This agrees with the findings of [39] who reported the MIC range of promethazine and cyproheptadine against MDR K. pneumoniae isolates to be $250-500 \mu \mathrm{g} / \mathrm{ml}$ and $125-250 \mu \mathrm{g} / \mathrm{ml}$ respectively. They also reported MIC values $\geq 1000 \mu \mathrm{g} / \mathrm{ml}$ for other tested antihistaminic drugs. On the contrary, [18] mentioned $200 \mu \mathrm{g} / \mathrm{ml}$ as MIC of diphenhydramine against several S. aureus, E. coli, K. pneumonia and P. mirabilis isolates far lower than the MICs values obtained in the present study.

The detected antibacterial activity of promethazine in the present work agreed with the results obtained by $[14,19,31]$ who showed that several phenothiazine antihistamines e.g. methdilazine and promethazine possess antibacterial capabilities. Furthermore, the obtained MIC range of promethazine was similar to the results obtained by $[16,40]$. Moreover, [41] reported that promethazine showed significant antibacterial action when tested against 124 strains of aerobic and 13 strains of anaerobic bacteria belonging to both Gram positive and Gram negative genera. The authors reported that the range of MIC $(\mu \mathrm{g} / \mathrm{ml})$ of promethazine varied between 50 and $200 \mu \mathrm{g} / \mathrm{ml}$ among most of the test organisms.

In the present study, no activity against MDR K. pneumoniae isolates was observed by cetrizine (MICs values $>1000 \mu \mathrm{g} / \mathrm{ml}$ ). On the contrary, [39] reported that cetrizine possessed a slight bacteriostatic activity, under the conditions of the test, against both tested Grampositive and Gram-negative bacteria. However, such study was performed on a total of 29 bacterial strains and clinical isolates. 


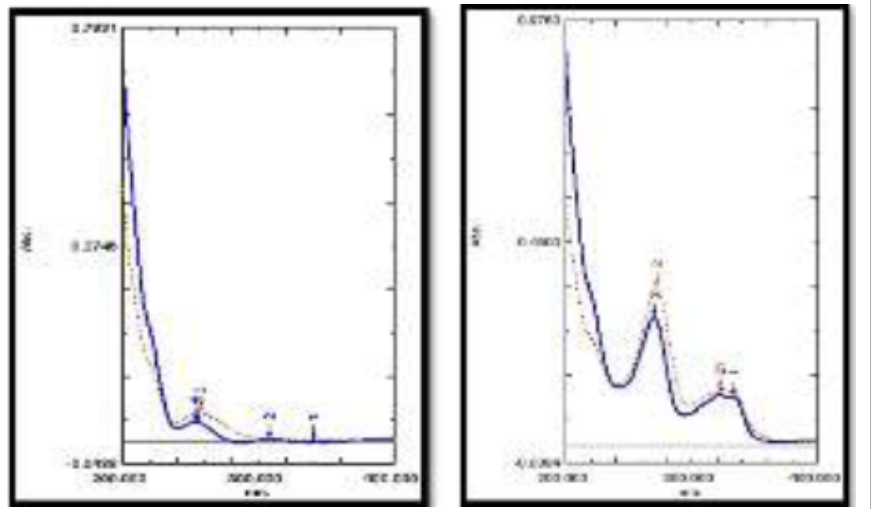

Figure 5: The electronic absorption spectra of: (a) diphenhydramine \& ciprofloxacin $\mathrm{HCl}$ combination. (b) diphenhydramine \& gentamicin sulfate combination.

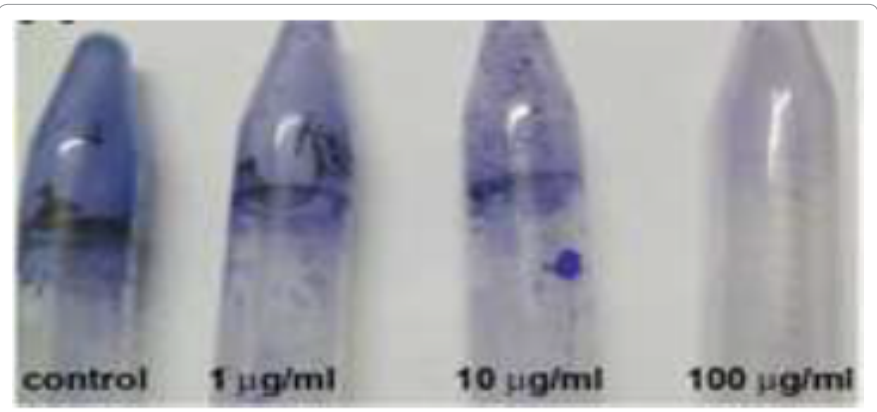

Figure 6: Reduction in biofilm production by $\mathrm{K} 33$ isolate treated with promethazine.

The variation in the magnitude of antibacterial effects among different antihistaminics is however difficult to explain since reviewing the literature revealed that no extensive studies were published on the antibacterial activity of the different categories of antihistaminic drugs. Thus, reviewing a possible explanation of such varied antimicrobial activity will be attempted. Such explanation may relate the mechanism of antibacterial action of antihistaminics to their chemical structure by analogy with other therapeutic classes having the same structural features [16]. Since the main structural feature of antihistaminics is a tertiary amino group and a bulky lipophilic aromatic moiety, they possess certain surfactant-like characters [42]. Owing to surface activity of these compounds, it has been reported that they might cause alteration in the function and permeability of biological membranes in general [43]. The extent of adsorption onto the membranes due to surface activity has been correlated with their damaging effects [44]. These postulates were investigated by [14] who demonstrated that certain phenothiazine antihistaminics could be adsorbed onto the surface of the bacterial cells which might facilitate their effect on their membranes. It has been stated that increasing the hydrophobicity increases the surface activity [45]. Therefore, based on this assumption, antihistaminics with the most powerful antibacterial activity should be the most surface-active and be highly hydrophobic [39]. Thus the high surface activity contributes to the recognizable antibacterial effects of promethazine. Similarly, cyproheptadine, having a considerable surface activity, manifested marked antibacterial effects in this respect; [46] reported that the phenothiazine acts as an electron donor at the surface of the plasma membrane of the cell or within the lipid bilayer of the plasma membrane, then the electron transfer on the outside will result in depolarization of the membrane. Because this depolarization reduces the activity of the plasma membrane (conductivity, etc.), the phenothiazine has been referred to as a membrane-stabilizing agent.

Other possibilities consistent with the data obtained in the current work include the binding of phenothiazines and their derivatives to the calcium-binding protein calmodulin to prevent the influx of calcium into eukaryotic cells [47]. This has prompted some investigators to propose similar mechanisms with respect to the influx and efflux of potassium into bacterial cells [48]. Besides, phenothiazines may also increase the permeability of the cell wall envelope as reported by $[49,50]$. They also may bind tightly to the minor groove of eukaryotic and bacterial DNA by intercalation between the base pairs [51] as is the case with their close relatives, the fluorescent dyes, thus presuming that inhibition of replication of affected microorganisms may take place by this mechanism [52].

Therefore, it may be concluded that the alteration of membrane permeability is one of the major mechanisms underlying the antibacterial effects of antihistaminics against the tested bacteria. The variation in the magnitude of the antibacterial effects among different antihistaminics was related to their varied capacities to induce membrane damage owing to differences in their extent of adsorption onto the cell membranes as well as differences in their surface activity [16].

In the present work, the antimicrobial activity of each of the selected drugs (promethazine, cyproheptadine) was studied using growth curve method. It was found that the selected drugs retarded the growth of the test organisms in a concentration-dependent manner. The level of this retardation differed according to the tested drugs.

In the present work, the susceptibility of 50 bacterial isolates of K. pneumoniae to each of 16 antimicrobial agents was determined by agar dilution method. Based on the antimicrobial resistance patterns of resistant isolates, multi-drug resistance (MDR) character was studied. MDR isolates were selected to be resistant to antibiotics belonging to at least 3 classes and up to all tested antibiotics [39].

In this study, the in vitro effects of combining each of the commonly prescribed antihistaminics with any of the tested antimicrobial agents against thirty MDR K. pneumoniae isolates were investigated. Marked synergistic effects against tested MDR isolates were commonly detected when the phenothiazine antihistaminic, promethazine, was used in combination with the macrolide; azithromycin against up to $50 \%$ of $K$. pneumoniae isolates. Also, significant synergism was detected in case of promethazine / ciprofloxacine combination against up to $60 \%$ of $K$. pneumoniae isolates.

Our results regarding the synergistic interactions of promethazine with the tested antibiotics came in accordance with the results obtained by [53] who tested the phenothiazines methylene blue and promethazine for their potential separate interaction with four representative antibiotics: ampicillin, erythromycin, gentamicin and tetracycline against E. coli, S. epidermidis and Ps. aeruginosa using the checkerboard method. The authors reported synergism to be observed with promethazine in combination with tetracycline and erythromycin against E. coli, S. epidermidis.

In the present work, marked synergism was also detected in 50\%$90 \%$ of MDR K. pneumoniae isolates when $10 \mu \mathrm{g} / \mathrm{ml}$ of the ethanolamine antihistaminic, diphenhydramine, was used in combination with a variety of antibiotics such as azithromycin, erythromycin, amikacin, gentamicin or ciprofloxacin. Also, synergy was detected when $10 \mu \mathrm{g} /$ $\mathrm{ml}$ cetrizine was used in combination with cefotaxime, amikacin 
Citation: El-Banna TES, Sonbol FI, El-Aziz AAA, Al-Fakharany OM (2016) Modulation of Antibiotic Efficacy against Klebsiella pneumoniae by Antihistaminic Drugs. J Med Microb Diagn 5: 225. doi:10.4172/2161-0703.1000225

Page 9 of 13

\begin{tabular}{|c|c|c|c|c|c|c|c|c|c|}
\hline \multirow[t]{2}{*}{ Tested organism } & \multirow{2}{*}{$\begin{array}{l}\text { Conc. }(\mu \mathrm{g} / \mathrm{ml}) \\
\text { Drug }\end{array}$} & \multicolumn{8}{|c|}{ Biofilm production score ${ }^{*}$} \\
\hline & & C & Diph & Chlore & Tri & Cet & Prom & Dim & Cyp \\
\hline \multirow{4}{*}{ K33 } & 0 & 3 & 3 & 3 & 3 & 3 & 3 & 3 & 3 \\
\hline & 1 & 3 & 3 & 3 & 3 & 3 & 3 & 3 & 3 \\
\hline & 10 & 3 & 3 & 3 & 3 & 3 & 2 & 3 & 3 \\
\hline & 100 & 3 & 3 & 3 & 3 & 3 & 1 & 3 & 3 \\
\hline
\end{tabular}

C; Control, Diph; Diphenhydramine, Chlore; Chlorepheniramine, Tri; Triprolidine, Cet; Cetrizine, Prom; Prpmethazine, Dim; Dimenhydrinate, Cyp; Cyproheptadine. 'Score 1; weak/none biofilm producer, Score 2; moderate biofilm producer, Score 3; strong/high biofilm producer.

Table 3: Effect of tested drugs on biofilm production by tested $\mathrm{K} 33$ isolate detected by tube method.

\begin{tabular}{|c|c|c|c|c|c|}
\hline \multirow[b]{2}{*}{ Biofilm producing isolate } & \multirow[b]{2}{*}{ Tested drug Conc. } & \multicolumn{2}{|c|}{ Mean OD values } & \multirow[b]{2}{*}{$\begin{array}{l}10 \\
\mu \mathrm{g} / \mathrm{ml}\end{array}$} & \multirow[b]{2}{*}{$\begin{array}{l}100 \\
\mu \mathrm{g} / \mathrm{ml}\end{array}$} \\
\hline & & $\begin{array}{l}0 \\
\mu \mathrm{g} / \mathrm{ml}\end{array}$ & $\begin{array}{l}1 \\
\mu \mathrm{g} / \mathrm{ml}\end{array}$ & & \\
\hline \multirow{7}{*}{ K 33} & Diph & 3.035 & 2.86 & 2.554 & 2.44 \\
\hline & Chlore & 3.035 & 2.768 & 2.732 & 2.713 \\
\hline & Tri & 3.035 & 2.482 & 2.423 & 2.428 \\
\hline & Cet & 3.035 & 2.8 & 2.8 & 2.795 \\
\hline & Prom & 3.035 & 2.228 & 1.738 & 1.171 \\
\hline & $\operatorname{Dim}$ & 3.035 & 2.55 & 2.54 & 2.51 \\
\hline & Cур & 3.035 & 3.005 & 2.97 & 2.965 \\
\hline
\end{tabular}

Diph; Diphenhydramine, Chlore; Chlorepheniramine, Tri; Triprolidine, Cet; Cetrizine, Prom; Prpmethazine, Dim; Dimenhydrinate, Cyp; Cyproheptadine.

Table 4: Effect of tested drugs on optical density (OD) values measured by ELISA auto reader.

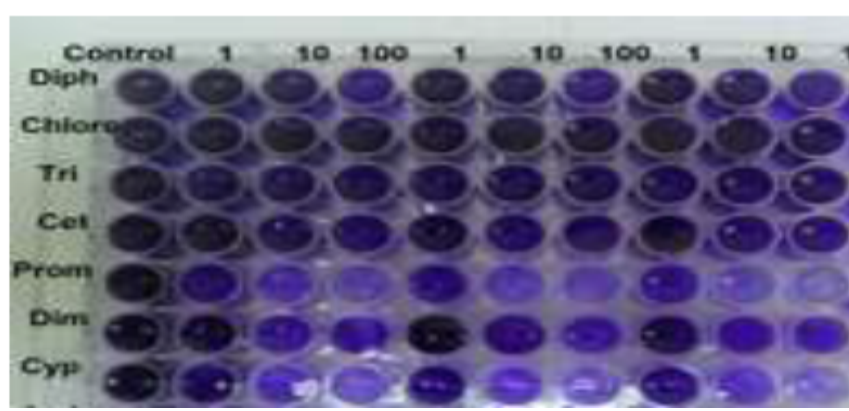

Figure 7: Tissue culture plate with 96 wells each filled with solubilized stained adhered biofilm produced, in the absence and presence of different concentrations $(\mu \mathrm{g} / \mathrm{ml})$ of tested drugs, by $\mathrm{K} 33$ isolate. ${ }^{*} \mathrm{C}$; Control, Diph; Diphenhydramine, Chlore; Chlorepheniramine, Tri; Triprolidine, Cet; Cetrizine, Prom; Prpmethazine, Dim; Dimenhydrinate, Cyp; Cyproheptadine.

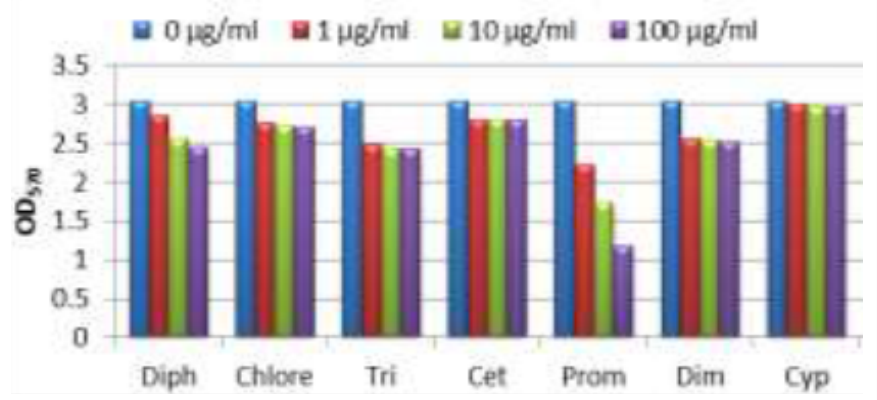

Figure 8: Effect of different concentrations of tested drugs on biofilm production by K33 isolate. Diph; Diphenhydramine, Chlore; Chlorepheniramine, Tri; Triprolidine, Cet; Cetrizine, Prom; Prpmethazine, Dim; Dimenhydrinate, Cyp; Cyproheptadine.

against up to $50 \%-80 \%$ of MDR K. pneumoniae isolates. In the current work, marked synergism up to $50 \%-80 \%$ of MDR K. pneumoniae isolates was also detected in case of triprolidine, chlorepheniramine or cyproheptadine combination with azithromycin.
The detected synergism between promethazine and the tested fluroquinolones can be explained by the fact that phenothiazines inhibit calcium binding to calmodulin or calmodulin-type proteins, much in the manner of the calcium channel verapamil, they may also affect all verapamil-sensitive efflux pumps [54,55]. On the contrary of the above mentioned findings, some antagonistic combinations were also experimentally detected in the present study. However, almost all of the antagonistic combinations were nonsignificant ( $<50 \%$ incidence).

In the present study, additional qualitative and/or quantitative tests were also performed in order to confirm the obtained results. One synergistic combination showing significant effect was chosen for further confirmation using efficiency of platting test. The selected synergistic combination was triprolidine / azithromycin combination against $K$. pneumoniae (K8) isolate.

Efficiency of plating (EOP) test is a measure of the number of colonies originating from single cells. It is very sensitive test and is often used for, determining the nutritional requirements of cells, measuring the effect of growth factors and for toxicity testing [56]. The present study revealed that selected drug produced a decrease in Log EOP of the tested bacterial isolate and such decrease was directly proportional to the concentration of the drug confirming synergism.

Possible physical interaction between selected drugs and different antimicrobial agents was investigated using electronic absorption spectrophotometric method. Representative example was selected from each of the aminoglycosides and fluroquinolones antibiotic categories. In case of aminoglycosides, gentamicin was chosen while from fluroquinolones, ciprofloxacin was selected. Synergistic combinations such as promethazine or diphenhydramine with gentamicin or ciprofloxacin were tested. The experimentally obtained UV spectra of these combinations were markedly different from their calculated spectra suggesting some sort of interaction or ionic association between such compounds.

In the present study, the effect of tested drugs on some strategies adopted by Gram-negative bacteria to resist antimicrobial agents were also investigated. These strategies include, first; bacterial biofilms where the concentration of the antimicrobial agent being actively reduced 


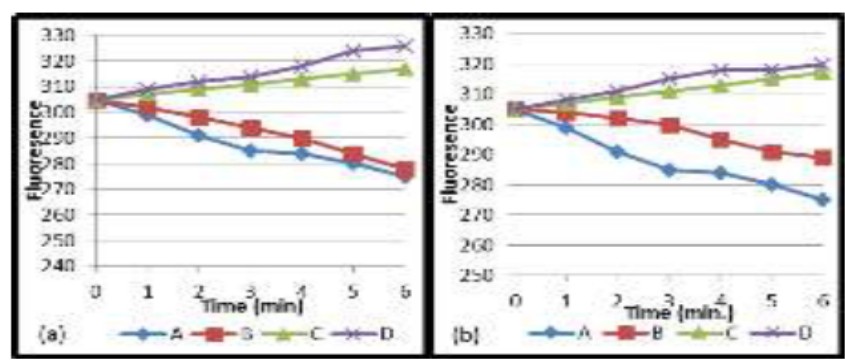

Figure 9: Effect of CCCP and/or (a) promethazine (b) cyproheptadine on NPN efflux by $(\mathrm{K} 6)$ isolate. A: untreated bacterial isolate, $\mathrm{B}$ : bacterial isolate overnight treated with $100 \mu \mathrm{g} / \mathrm{ml}$ of drug, C: bacterial isolate treated with CCCP, D: bacterial isolate treated with $100 \mu \mathrm{g} / \mathrm{ml}$ of drug then treated with CCCP.

(a)

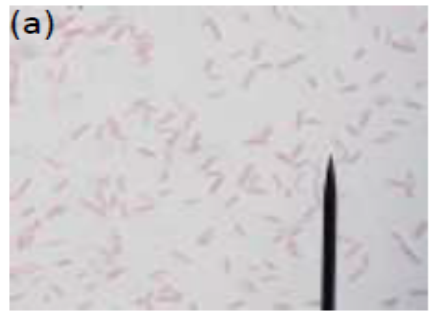

Figure 10: Gram's stained film of $K$. pneumoniae cells: (a) Untreated separate rod shaped cells, (b) Cells treated with $100 \mu \mathrm{g} / \mathrm{ml}$ chlorpheniramine showing long filaments.

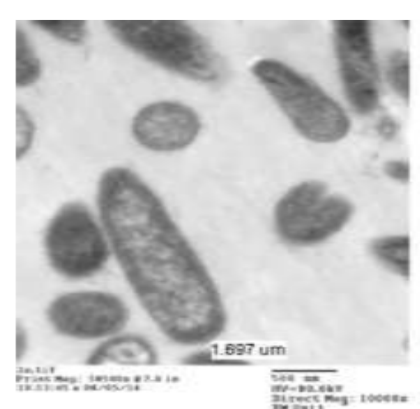

(a)

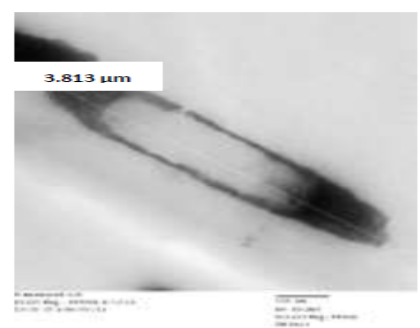

(c)

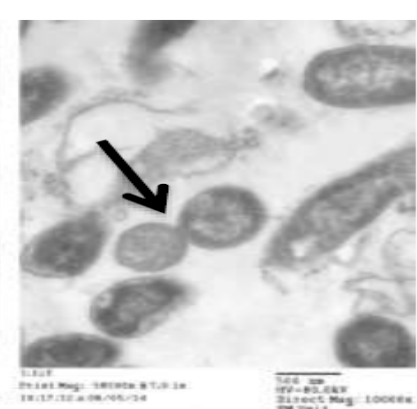

(b)

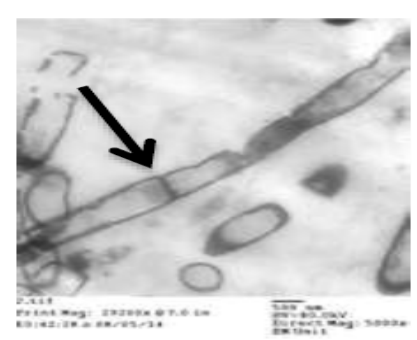

(d)
Figure 11: Transmission electron micrograph of $K$. pneumoniae cells: (a) Untreated cells with normal size (b) Untreated cells showing septum formation with cell separation. (c) Treated cells with chlorpheniramine showing elongation of cells. (d) Treated cells with chlorpheniramine showing filamentation due to septum formation with no separation of cells.

as it interacts and penetrates different layers of the microorganisms constituting biofilm. Second; bacterial efflux pump.

Biofilm infections, such as pneumonia in cystic fibrosis patients, chronic wounds, chronic otitis media and implant and catheter associated infections, affect millions of people in the developed world each year and many deaths occur as a consequence [57]. The present study revealed that most of the tested drugs showed effect on biofilm production, this effect differ in a concentration- and drug- dependent manner. Only promethazine showed considerable reduction in biofilm production by $K$. pneumoniae. This retardation was maximum at 100 $\mu \mathrm{g} / \mathrm{ml}$ concentration of promethazine whereas the tested K. pneumonia (K33) isolate transferred to non-biofilm producer by such drug treatment. In this respect, a possible explanation of the experimentally detected antibiofilm activity of promethazine is that being a phenothiazine derivative; it can inhibit quorum sensing leading to inhibition of biofilm formation [58]; studied the inhibition of quorum sensing (QS) by phenothiazines and structurally related molecules. Among the most effective inhibitors of QS was promethazine. The inhibition of QS signal transmission appears to be related to the quasi-planar structure and electron donor capacity of the conjugated $\pi$-electron system of the tricyclic framework. The authors postulated that these results can be exploited in rational drug design as a new way to reduce the QS mediated processes e.g. virulence of pathogens to vary the formation of biofilms and to modify antibiotic resistance. In the present work, the observed antibiofilm activity of promethazine can be also explained based on the findings of [59] who found that promethazine may affect the specific pilimediated and plasmidencoded adhesion and/or multiplication of bacteria on epithelial cells. The results obtained by $[60,61]$ were in agreement with results obtained in the present study regarding the antibiofilm activity of promethazine. The authors investigated promethazine and imipramine in the inhibition of adhesion of nephropathogenic E. coli strains in tissue culture using scanning electron microscopy. They found that in addition to the direct antibacterial effect, it can be presumed that a low concentration of promethazine and imipramine can inhibit the reversible and irreversible attachment of bacteria to epithelial cells, since both drugs interfere with the function of the microfilaments of cells and bacteria via membrane effects.

Efflux pump exist in all living cells, but those in the bacterial and mammalian cells are more important to the clinician and pharmacologist, as they constitute an important cause of antimicrobial drug resistance, which contributes to treatment failure, high medical bills, and increased mortality / morbidity. Multidrug resistance efflux pumps have now been described in both Grampositive and Gramnegative bacterial pathogens. As Gram-negative bacteria usually have a thick outer wall protection, which does not allow easy access of substances, the effects of efflux pumps and consequently efflux pump inhibitors are more pronounced in them as compared to the Grampositive organisms [62]. Resistance-Nodulation-Division (RND) efflux pumps are one of the most important determinants of multidrug resistance (MDR) in Gram-negative bacteria [63].

In the present study the effect of carbonyl cyanide mchlorophenylhydrazone (CCCP) and/or tested drugs on N-phenyl1-naphythylamine (NPN) efflux by K. pneumoniae was investigated. It was found that promethazine and cyproheptadine showed marked effect on bacterial efflux system as indicated by decrease in fluorescence values measured by spectrofluorometer. The results obtained in the present work came in agreement with [64] who reported that a proton pump deleted mutant E. coli had greater sensitivity to ampicillin, tetracycline and erythromycin than the wild type parent E. coli containing the proton pump. This antibiotic sensitivity was further increased by resistance modifiers such as the $\mathrm{Ca}_{2}{ }^{+}$channel blocker, verapamil and the calmodulin antagonist, promethazine. Furthermore, [15] reported that the phenothiazines have been shown to inhibit efflux 
pumps in general, and bacterial efflux pumps specifically. Moreover, [55] reported that phenothiazines may affect all verapamil-sensitive efflux pumps. In addition, bacterial ABC efflux pumps that transport potassium and calcium are readily inhibited by phenothiazines. The results obtained in the present work could be explained based on the finding that phenothiazines have their primary effects on the plasma membrane of prokaryotes and eukaryotes. Among the components of the prokaryotic plasma membrane affected are efflux pumps, their energy sources, energy providing enzymes such as ATPases, and genes that regulate and code for permeability aspects of the bacterium [55].

In the current study, the effect of the tested drugs on cell morphology was also examined. Microscopical examination of chlorephenraminetreated $K$. pneumoniae revealed the conversion of separate rod-shaped cells to long filaments. Moreover, electron microscope examination revealed septum formation with prevention of cell separation of the treated cells which explained the formation of long filaments. The result obtained in the present study came in agreement with $[4,65]$ who reported that with respect to bacteria, the morphological responses of phenothiazine-affected cells are remarkably similar to those produced when such bacteria are exposed to concentrations of $\beta$-lactams below their minimum inhibitory concentration (MIC), thus suggesting that in some manner they inhibit one or more of the penicillin binding proteins of the plasma membrane of affected bacteria leading to filamentation of Gram-negative bacterial cells. The effects of chlorpromazine on the morphology of Escherichia coli also mimic the effects of ampicillin, in that both effects of ampicillin, in that both produce significant elongation of the organism. B-lactams at subinhibitory concentrations inhibit the hydrolytic enzymes that would normally cause the separation of the replicated cells from each other [66]. Thus chlorpheniramine having two aromatic ring system might be considered as incomplete phenothiazine and so it could cause filamentation of treated K. pneumoniae cells.

In conclusion, the data obtained in this work showed that, among the tested drugs promethazine and cyproheptadine exerted high antibacterial activity against MDR K. pneumoniae isolates. So, it is possible to take the advantages of the obtained findings to introduce new ways to overcome different infectious diseases. Some of these drugs can show their antibacterial effects at routine doses. However, sometimes these routine doses are lower than the antibacterial doses and the in-vitro antimicrobial activity of these non-antibiotics are produced by concentrations that far exceed those that would be employed for the management of pathological conditions. When that is the case, the development of several non-toxic derivatives or analogies for these non-antibiotics may be another approach for the use of these drugs in the management of pathological conditions. Promethazine had decreased biofilm formation by K. pneumonia (K33) MDR isolate. Taken together, the findings of the present study open up a new possibility of interfering with bacterial adhesiveness and its resulting pathogenicity by agents devoid of antibacterial activity.

The tested drugs were also found to positively or negatively affect the activity of various antibiotics against MDR K. pneumoniae isolates. The enhancement of antibiotic activity or the reversal of antibiotic resistance by non-conventional antibiotics affords the classification of the tested drugs as modifiers of antibiotic activity $[67,68]$. The observed synergistic interactions were explained by inhibition of efflux pumps and inhibition of biofilm formation. Since the use of antihistaminics in the drug regimen for patients who acquire microbial infection is inevitable, so and their use as adjuvants for therapy of MDR bacterial infections mediated by over-expressed efflux pumps is promising. On the other hand, the observed antagonistic combinations should be avoided in order to save antibiotics efficacy.

These recorded in vitro interactions are shedding light on the possibility of similar occurrence, in vivo. Accordingly, further studies are required including in vivo experiments and clinical trials to put these new agents into clinical use and also to select potentially useful combinations and avoid the harmful ones before the clinical use of these drugs in combinations with different antimicrobial agent. As of the time of this writing, there is much interest in the potential of medicinal compounds for adjunct use. However, because these agents are no longer under patent protection and they present no economic advantage to pharmaceutical companies, there is resistance to their development for therapy of infectious disease. However, the message that non-antibiotics offer a potential to serve as adjuncts for the therapy of MDR infections is being heard. Hopefully, we will see clinical trials for therapy of problematic MDR bacterial infections with non-antibiotics in the near future. Finally, it possible to take advantage of these synergistic combinations by reducing the dose of antibiotic which is useful in hepatic or renal patients specially in case of fluoroquionlones which had several potential annoying side effects that can be overcome by decreasing the dose.

\section{References}

1. Ejim L, Farha MA, Falconer SB, Wildenhain J, Coombes BK, et al. (2011) Combination of antibiotics and nonantibiotic drugs enhance antimicrobial efficacy. Nat Chem Biol 7: 348-350.

2. Piddock LJ (2006) Multidrug-resistance efflux pumps- not just for resistance. Nat Rev Microbiol 4: 629-636.

3. Lomovskaya O, Zgurskaya HI, Totrov M, Watkins WJ (2007) Waltzing transporters and 'the dance macabre' between humans and bacteria. Nat Rev Drug Discov 6: 56-65.

4. Amaral L, Kristiansen JE, Abebe LS, Millet W (1996) Inhibition of the respiration of multi-drug resistant clinical isolates of Mvcobacterium tuberculosis by thioridazine: potential use for initial therapy of freshly diagnosed tuberculosis. $J$ Antimicrob Chemother 38: 1049-1053.

5. Martins M, Dastidar SG, Fanning S, Kristiansen JE, Molnar J, et al. (2008) Potential role of nonantibiotics (helper compounds) in the treatment of multidrug-resistant Gram-negative infections: mechanisms for their direct and indirect activities. Int J Antimicrob Agents 31: 198-208.

6. Sicherer, Scott HMD (2006) Understanding and Managing Your Child's Food Allergy. Baltimore: The Johns Hopkins University Press.

7. Criado PR, Fachini R, Criado J, Maruta CW (2010) Histamine, histamine receptors and antihistamines: new concepts. An Bras Dermatol 85: 195-210.

8. Jutel M, Bblaser K, Akdis CA (2005) Histamine in chronic allergic responses. J Invest Allergol Clin Immunol 15: 1-8.

9. Van Schoor J (2012) Antihistamines: a brief review. Clinical 16.

10. Martindale (1996) In: Reynolds JEF (Ed.). The Extra Pharmacopoeia (31thedn) Londres. The Royal Pharmaceutical Society.

11. Molnar J, Haszon I, Bodrogi T, Martonyi E, Turi S (1990) Synergistic effect of promethazine with gentamicin recurring pyelonephritis. Int Urol Nephrol 22: 405-411.

12. Neu HC (1994) Antimicrobial chemotherapy. Antimicrob infect dis newsl 13 $1-8$

13. Chattopadhyay D, Dastidar SG, Chakrabarty AN (1987) Determination of in vitro antibacterial activity of methdilazine, an antihistamine, and its synergism with aminoglycoside antibiotics. Indian J Med Microbiol 5: 171-7.

14. Shibl AM, Hammouda Y, Al-Sowaygh I (1984) Comparative effects of selected phenothiazine tranquilizers and antihistaminics on bacterial cells and possible interactions with antibiotics. J Pharm Sci 73: 841-843.

15. Molnar J, Hever A, Fakla I, Fischer J, Ocsovski I, et al. (1997) Inhibition of the transport function of membrane proteins by some substituted phenothiazines in multidrug resistant E. coli and tumor cells. Anticancer Res 17: 481-486. 
Citation: El-Banna TES, Sonbol FI, El-Aziz AAA, Al-Fakharany OM (2016) Modulation of Antibiotic Efficacy against Klebsiella pneumoniae by Antihistaminic Drugs. J Med Microb Diagn 5: 225. doi:10.4172/2161-0703.1000225

16. El-Nakeeb MA, Abou-Shleib HM, Khalil AM, Omar HG, El-Halfawy OM (2011) In vitro antibacterial activity of some antihistaminics belonging to different groups against multi-drug resistant clinical isolates. Braz. J. Microbiol 42: 3.

17. Dastidar SG, Saha PK, Sanyamat B, Chakrabarty AN (1976) Antibacterial activity of ambodryl and benadryl. J Appl Bacteriol 41: 209-214.

18. Dash SK, Dastidar SG, Chakrabarty AN (1977) Antibacterial property of promazine hydrochloride. Indian J Exp Biol 15: 324-326.

19. Chattopadhyay D, Dastidar SG, Chakrabarty AN (1988) Antimicrobial property of methdilazine and its synergism with antibiotics and some chemotherapeutic agents. Arzneimittelforschung $38: 869-872$.

20. Koneman EW, Allen SD, Jand WM, Schreckenberger PC, Winn WC (1992) The enterobacteriaceae: In Color Atlas and Text Book of Diagnostic Microbiology (4thedn) JB Lippincott Co., Philadelphia 105

21. Cheesbrough M (2000) District Laboratory Practice in Tropical countries. Canbrioge University press 182-184.

22. CLSI-Clinical and Laboratory Standards Institute (2010) Performance standards for antimicrobial susceptibility testing; twentieth informational supplement. CLSI document M100-S20. Clinical and Laboratory Standards Institute, 940 West Valley Road, Suite 1400, Wayne, Pennsylvania 19087-1898 USA.

23. Shohayeb M, EL-Banna T, Sonbol F (1997) Effect of salicylate on Staphylococcus aureus and its susceptibility to antimicrobials. Egypt $\mathrm{J}$ Med Microbiol 6: 1.

24. Williams DN, Ehrman SH, Holoman TRP (2006) Evaluation of the microbial growth response to inorganic nanoparticles. J Nanobiotechnology 4: 3 .

25. 25. Cursino L, Chartone ES, Nascimento AMA (2005) Synergic interaction between ascorbic acid and antibiotics against Pseudomonas aeruginosa. Braz arch biol technol 48

26. Mackay ML, Milne K, Gould IM (2000) Comparisons of the methods for assessing synergic antibiotic interactions. Int J Antimicrob Agents 15: 125-129.

27. Odds FE (2003) Synergy, antagonism, and what the chequerboard puts between them. J Antimicrob. Chemother 52: 1.

28. Sweeney MT, Zurenko GE (2003) In Vitro Activities of Linezolid Combined with Other Antimicrobial Agents against Staphylococci, Enterococci, Pneumococciand Selected gram- Negative Organisms. Antimicrob. Agents Chemother 47: 1902-1906.

29. Aumercier M, Murray DM, Rosner JL (1990) Potentiation of susceptibility to aminoglycosides by salicylates in Escherichia coli. Antimicrob Agents Chemother 34: 786-791.

30. Toama MeA, El-Fatatry HH, El-Falaha B (1978) In vitro studies in drugantibiotic interactions: analgesics, antipyretics, antimalarials and tranquilizers. J Pharm Sci 67: 23-26.

31. El-Banna T (1983) In vitro study of certain drugsantibiotic interactions. M.Sc. Thesis, Faculty of Pharmacy, Tanta University, Tanta, Egypt.

32. Holt SC, Gauther JJ, Tipper DJ (1975) Ultrastructural studies of sporulation in Bacillus sphaericus. J Bacteriol 122: 1322-1338.

33. McDowell EM, Trump BF (1976) Histologic fixatives suitable for diagnostic light and electron microscopy. Arch Pathol Lab Med 100: 405-414.

34. Christensen GD, Simpson WA, Younger JJ, Baddour LM, Barrett FF, et al. (1985) Adherence of coagulase negative Staphylococci to plastic tissue culture plates: a quantitative model for the adherence of Staphylococci to medical devices. J Clin Microbiol 22: 996-1006.

35. Mathur T, Singhal S, Khan S, Upadhyay DJ, Fatma T, et al. (2006) Detection of biofilm formation among the clinical isolates of Staphylococci: an evaluation of three screening methods. Indian J Med Microbiol 24: 25-29.

36. Mazumdar R, Ganguly K, Dastidar SG, Chakrabarty AN (2001) Trifluoperazine: A broad-spectrum bactericide specially active on staphylococci and vibrios. Int J Antimicrob Agents 18: 403-406.

37. Trauble H, Overath P (1973) The structure of E. coli membranes studied by fluorescence measurements of lipid phase transition. Biochim Biophys Acta 307: 491.

38. Mullin S, Mani N, Grossman TH (2004) Inhibition of antibiotic efflux in bacteria by the novel Multidrug resistance inhibitors biricodar (VX-710) and timcodar (VX-853). Antimicrob Agents Chemother 48: $4171-4176$.
39. El-Nakeeb MA, Abou-Shleib HM, Khalil AM, Omar HG, El-Halfawy OM (2011) Membrane permeability alteration of some bacterial clinical isolates by selected antihistaminics. Braz J Microbiol 42: 992-1000.

40. Molnar J, Mandi, Y, Kiraly J (1976) Antibacterial effect of some phenothiazine compounds

41. and R-factor elimination by chlorpromazine. Acta Microbiol Acad Sci Hung 23: 45-54.

42. Chakrabarty AN, Acharya DP, Neogi D, Dastidar SG (1989) Drug interaction of promethazine \& other nonconventional antimicrobial chemotherapeutic agents. Indian J Med Res 89: 233-237.

43. Attwood D, Florence AT (1998) Physicochemical principles of pharmacy Macmillan, London 199-250.

44. Guth PS, Spirtes MA (1964) The Phenothiazine tranquilizers: Biochemical and Biophysical Actions. Int Rev Neurobiol 7: 231-278.

45. Attwood D, Florence AT (1983) Surfactant systems: Their chemistry, pharmacy and biology. Chapman and Hall Ltd., London 124-228, 388-468, 607-610.

46. Attwood D, Udeala OK (1975) The surface activity of some antihistamines at the air-solution interface. J Pharm Pharmacol 27: 754-758.

47. Dastidar SG, Kristiansen JE, Molnar J, Amaral L (2013) Role of phenothiazines and structurally similar compounds of plant origin in the fight against infections by drug resistant bacteria. Antibiotics 2: 58-72.

48. Motohashi N (1991) Phenothiazines and calmodulin (Review). Anticancer Res 11: $1125-1164$.

49. Molnar J, Ren J, Kristiansen JE, Nakamura MJ (1992) Effects of some tricyclic psychopharmacons and structurally related compounds on motility of Proteus vulgaris. Antoine Van Leeuwenhoek 62: 319-320.

50. Amaral L, Lorian V (1991) Effects of chlorpromazine on the cell envelope proteins of Escherichia coli. Antimicrob Agents Chemother 30: 556-558.

51. Amaral L, Kristiansen JE (2000) Phenothiazines: an alternative to conventional management of suspect multidrug resistant tuberculosis. Int $\mathrm{J}$ Antimicrob Agents 14: 173-176.

52. Hagmar P, Pierrou S, Nielsen P, Norden B, Kubista M (1992) lonic strength dependence of the binding of methylene blue tochromatin and calf thymus DNA. J Biomol Struct Dyn 9: 667-679.

53. Yashima E, Tajima T, Suehiro N, Akashi M, Miyauchi N (1990) Study on the interaction of aromatic dyes with nucleic acids by means of UV, CD and NMR spectroscopies. Nucleic Acids Symp Ser (Oxf) 22: 101-102.

54. Gunics GN, Mtohashi L, Amaral SF, Molnar J (2000) Interaction between antibiotics- and non-conventional antibiotics on different bacteria. Antimicrob Agents Chemother 14: 239-242.

55. Amaral L, Viveiros M, Kristiansen JE (2006) "Non-Antibiotics": alternative therapy for the management of MDR TB and MRSA in economically disadvantaged countries. Curr Drug Targets 7: 887-891.

56. Amaral L, Viveiros M, Molnar J (2004) Antimicrobial activity of phenothiazines. In Vivo 18: 725-731.

57. Mather JP, Roberts PE (1998) Introduction to cell and tissue culture: theory and technique. Plenum Press, New York and London.

58. Bjarnsholt T (2013) The role of bacterial biofilms in chronic infections. APMIS Suppl 136: 1-51.

59. Varga ZG, Szabo MA, Schelz Z, Szegedi Z, Jozsef (2011) Quorum Sensing Inhibition by Phenothiazines and Related Compounds. Lett Drug Des Discov 8: 133-137.

60. Kasler M, Poczik M, Molnar J, Agoston E (1982) The Pipolphen plazmidtorlo Examination of the impact of urogenital infections. Urol Nephrol Review 9: 130-

61. Hirota Y (1960) The effect of acridine dyes on mating type factors in Escherichia coli. Proc Natl Acad Sci 46: 57-64.

62. Molnar J, Mucsi I, Kasa P (1983) Inhibition of the adhesion of E. coli on cultured human epithelial cells in the presence of promethazine or imipramine. Zentralb Bakteriol Mikrobiol Hyg [A] 254: 388-396.

63. Ughachukwu PO, Unekwe PC (2012) Efflux pumpmediated resistance in chemotherapy. Ann Med Health Sci Res 2: 191-198. 
Citation: El-Banna TES, Sonbol FI, El-Aziz AAA, Al-Fakharany OM (2016) Modulation of Antibiotic Efficacy against Klebsiella pneumoniae by Antihistaminic Drugs. J Med Microb Diagn 5: 225. doi:10.4172/2161-0703.1000225

Page 13 of 13

64. Dinesh M, Fernando, Ayush Kumar (2013) Resistance-nodulation-division multidrug efflux pumps in Gram-negative bacteria. Antibiotics 2: 163-181.

65. Wolfart K, Spengler G, Kawase M, Motohashi N, Molnar J, et al. (2006) Synergistic interaction between proton pump inhibitors and resistance modifiers and plasmid curing. In Vivo 20: 367-372.

66. Amaral L, Lorian V (1991) Effects of chlorpromazine on the cell envelope proteins of Escherichia coli. Antimicrob Agents Chemother 35: 1923-1924.
67. Lorian V, Atkinson B (1980) Killing of oxacillinexposed staphylococci in human polymorphonuclear leukocytes. Antimicrob Agents Chemother 18: 807-813.

68. Mazumdar K, Asok Kumar K, Dutta NK (2010) Potential role of the cardiovascular non-antibiotic (helper compound) amlodipine in the treatment of microbial infections: scope and hope for the future. Int J Antimicrob Agents 36: 295-302.

69. Martins A, Hunyadi A, Amaral L (2013) Mechanisms of Resistance in Bacteria An Evolutionary Approach. Open Microbiol J 7: 53-58. 